\title{
GAMBARAN KOMPETENSI PROFESIONAL GURU PAUD MANGGA PANINGGILAN CILEDUG
}

\author{
Dyah Novitasari $^{1}$; Nila Fitria ${ }^{1}$ \\ ${ }^{1}$ Program Studi Pendidikan Guru Pendidikan Anak Usia Dini, Fakultas Psikologi dan Pendidikan, \\ Universitas Al Azhar Indonesia, Jalan Sisingamangaraja Kebayoran baru, Jakarta Selatan 12110 \\ Penulis untuk Korespondensi/E-mail: nilafitria@uai.ac.id.
}

\begin{abstract}
Abstrak - Guru Pendidikan Anak Usia Dini (PAUD) yang berkualitas memiliki kompetensi profesional yang tinggi dalam melaksanakan tugasnya yaitu dapat menyusun materi serta kegiatan yang kreatif, mendidik dan mengajar siswa serta menganalisis perkembangan anak didik sesuai tahapanperkembangannya.Sedemikian berat tugas dan tanggung jawab guru, maka dalam proses pembelajarannya diperlukan guru yang profesional, dan yang berkompeten. Maka dari itu guna meningkatkan profesionalisme guru, perlu dilakukan pelatihan dan penataran yang intens pada guru. Atas dasar itulah peneliti tertarik untuk meneliti bagaimana Gambaran Kompetensi Profesional Guru Paud Mangga Paninggilan Ciledug. Metode yang digunakan peneliti dalam penelitian ini adalah metode penelitian deskriptif kualitatif. Berdasarkan hasil penelitian ini dapat dilihat gambaran kemampuan kompetensi professional guru yang dimiliki oleh guru PAUD Mangga Paninggilan. Guru sudah mampu menyusun serta menciptakan materi kegiatan yang kreatif serta sesuai dengan tahapan perkembangan anak didik. Namun guru masih perlu mengembangkan kemampuannya dengan melakukan penelitian tindakan kelas.
\end{abstract}

Kata Kunci: Kompetensi Profesional, Guru, PAUD

Abstract - Teachers of Early Childhood Education (PAUD) have aquality high professional competence in carrying out their duties, namely being able to compile creative materials and activities, educate and teach students and analyze the development of students according to their developmental stages. The task and responsibility of the teacher is so heavy, that in the learning process, professional and competent teachers are needed. Therefore, in order to increase teacher professionalism, intense training and upgrading of teachers is necessary. On this basis, researchers are interested in examining how the Professional Competence of Paud Mangga Paninggilan Ciledug Teachers. The method used by researchers in this research is descriptive qualitative research methods. Based on the results of this study, it can be seen that a description of the professional competence of teachers possessed by Mangga Paninggilan PAUD teachers. The teacher is able to compile and create creative activity material in accordance with the stages of the development of students. However, teachers still need to develop their abilities by conducting classroom action research.

Keywords: Professional Competence, Teachers, PAUD

\section{PENDAHULUAN}

$\mathrm{P}$ endidikan Anak Usia Dini (PAUD) merupakan pendidikan yang paling mendasar menempati posisi yang paling strategis dalam pengembangan sumber daya manusia. Berbagai studi telah membuktikan bahwa pengembangan Pendidikan Anak Usia Dini (PAUD) merupakan investasi yang strategis dalam meningkatkan kualitas Sumber Daya Manusia (SDM).

Guru dituntut memiliki segenap kompetensi antara lain kompetensi pedagogik, kompetensi sosial, kompetensi kepribadian, dan kompetensi profesional yang satu sama lain terintegrasi dalam kepribadiannya secara utuh. Namun kenyataan di lapangan, sering kali pendidik 
tidak mempunyai kompetensi penuh dalam melaksanakan tugas-tugasnya.

Undang-undang Republik Indonesia Nomor 14 Tahun 2005 tentang Undang-undang Guru dan Dosen, tepatnya pada BAB III Pasal 7 diamanatkan bahwa guru memegang peran penting dan strategis dalam pendidikan.Guru Pendidikan Anak Usia Dini (PAUD) yang berkualitas memiliki kompetensi profesional yang tinggi dalam melaksanakan tugasnya yaitu dapat membimbing, menyusun materi serta kegiatan yang kreatif, mendidik dan mengajar siswa sesuai tahap perkembangannya. Sedemikian berat tugas dan tanggung jawab guru, maka dalam proses pembelajarannya diperlukan guru yang profesional, dan yang berkompeten. Guru yang kompeten akan lebih mampu menciptakan lingkungan belajar yang efektif dan akan lebih mampu mengelola kelasnya sehingga hasil belajar siswa berada pada tingkat optimal.

Memahami realitas dilapangan memperlihatkan bahwa semakin besarnya harapan yang digantungkan masyarakat terhadap tugas guru dalam upaya meningkatkan kualitas pendidikan, senantiasa mengalami beberapa hambatanhambatan. Oleh karena itulah, upaya dari pengelolaPAUDatau organisasi profesi terkait dalam peningkatkan profesionalisme guru dalam kegiatan belajar mengajar di sekolah melalui, pemberian pelatihan atau pembinaan sangatlah berpengaruh terhadap peningkatan kompetensi mengajar guru.

Berdasarkan Peraturan Menteri Pendidikan Republik Indonesia Nomor 137 tahun 2014 BAB VII tentang Standar Pendidik Dan Tenaga Kependidikan disebutkan bahwa guru PAUD merupakan tenaga profesional yang memiliki kualifikasi akademik dan kompetensi pendidik sekurang-kurangnya Diploma Empat (D-IV) atau Sarjana (S-1) di bidang Pendidikan Anak Usia Dini (S-1/D-IV PG.PAUD), kependidikan lain atau psikologi dan memiliki sertifikasi profesi guru PAUD atau sekurang-kurangnya telah mendapat pelatihan pendidikan anak usia dini.Kompetensi profesional merupakan kemampuan yang berkenaan dengan penguasaan materi pembelajaran bidang studi secara luas dan mendalam.Sebagai lembaga pendidikan formal, tentu guru menjadi ujung tombak keberhasilan proses pendidikan di sekolah tersebut. Oleh karena itu diperlukan guru yang mampu melaksanakan pembelajaran secara profesional.

Peningkatan mutu guru yang dilakukan tidak akan lepas dari peningkatan kompetensi guru. Tujuan dikembangkan standar kompetensi guru adalah untuk menetapkan suatu ukuran kemampuan pengetahuan dan keterampilan yang harus dikuasai oleh seorang guru agar profesional dalam merencanakan dan mengelola proses pembelajaran di sekolah. Pada penelitian ini peneliti ingin mengetahui gambaran kemampuan kompetensi professional guru di PAUD Mangga Paninggilan. Dalam peraturan Pemerintah Republik Indonesia Nomor 19 Tahun 2005 tentang Standar Nasional Pendidikan pasal 28 ayat 3 butir "c", di kemukakan bahwa kompetensi professional adalah kemampuan penguasaan materi pembelajaran secara luas dan mendalam yang memungkinkannya membimbing peserta didik memenuhi standar kompetensi yang ditetapkan dalam Standar Nasional Pendidikan.

Namun dari hasil observasi yang peneliti lakukan antara lain guru dalam pelaksanaan kegiatan pembelajaran dirasa belum mampu menguasai materi secara maksimal dan terlihat belum dapat mengembangkan materi dalam pembelajaran, tetapi guru berupaya mengajar dengan model pembelajaran yang kreatif, guru juga sangat sayang kepada peserta didik serta sangat mengayomi peserta didik. Dalam penyusunan guru belum mampu menguasai standar kompetensi dasar dalam pembuatan Rencana Pelaksanaan Pembelajaran Mingguan (RPPM) dan Rencana Pelaksanaan Pembelajaran Harian (RPPH), namun guru sudah mampudalam memanfaatkaan teknologi dengan baik dalam proses pembelajaran maupun dalam penyusunan Program Tahunan (Prota), Program Semester (Promes), Rencana Pelaksanaan Pembelajaran Mingguan (RPPM) dan Rencana Pelaksanaan Pembelajaran Harian (RPPH).

Dari pendahuluan yang penulis lakukan melalui wawancara dengan Kepala Lembaga PAUD Mangga Paninggilan, diperoleh informasi bahwa guru di PAUD Mangga paninggilan dalam aktivitas sehari-harinya berusaha melakukan tugasnya secara professional sesuai dengan kompetensi professional guru. Namun 
dari hasil observasi yang peneliti lakukan antara lain guru dalam pelaksanaan kegiatan pembelajaran dirasa belum mampu menguasai materi secara maksimal dan terlihat belum dapat mengembangkan materi dalam pembelajaran, tetapi guru berupaya mengajar dengan model pembelajaran yang kreatif, guru juga sangat sayang kepada peserta didik serta sangat mengayomi peserta didik.

Kompetensi merupakan seperangkat pengetahuan yang harus dimiliki oleh setiap tenaga pendidik untuk melaksanakan tugasnya yaitu mendidik. Seperti yang dijelaskan oleh Pupuh dan M. Sobry Surikno (dalam Ali Mudlofir 2012: 44) kompetensi adalah seperangkat tindakan inteligen penuh tanggung jawab yang harus dimiliki seseorang sebagai syarat untuk dianggap mampu melaksanakan tugas-tugas dalam bidang pekerjaan tertentu. Kompetensi dalam bahasa Indonesia merupakan serapan dari bahasa Inggris, competence yang berarti kecakapan dan kemampuan. Dalam Undang-undang Nomor 14 Tahun 2005 tentang Guru dan Dosen, mengemukakan bahwa kompetensi adalah seperangkat pengetahuan, keterampilan, dan perilaku yang harus dimiliki, dihayati, dan dikuasai oleh guru atau dosen dalam melaksanakan tugas keprofesionalan. Menurut Usman (2011: 5) guru merupakan jabatan atau profesi yang memerlukan keahlihan khusus sebagai guru, seorang yang menjadi guru bukanlah asal orang yang pandai berbicara melainkan seseorang yang telah menjalani jenjang pendidikan tertentu dan memiliki pengalaman mengajar

Peraturan Pemerintah No. 19 Tahun 2005 tentang Standar Nasional Pendidikan, Kompetensi Profesional dalam Standar Nasional Pendidikan, yang dijelaskan dalam pasal 28 ayat (3) butir c adalah kemampuan penguasaan materi pembelajaran secara luas dan mendalam yang memungkinkannya membimbing peserta didik memenuhi standar kompetensi yang di tetapkan dalam Standar Nasional Pendidikan.Indikator kompetensi professional meliputi: (a) Kemampuan untuk mengusai landasan kependidikan, misalnya paham akan tujuan pendidikan yang harus dicapai baik tujuan nasional, institusional, kurikuler dan tujuan pembelajaran. (b) Pemahaman dalam bidang psikologi pendidikan, (c) Kemampuan dalam penguasaan materi pelajaran sesuai dengan bidang studi yang diajarkan. (d) Kemampuan dalam mengaplikasikan berbagai metodologi dan strategi pembelajaran. (e) Kemampuan merancang dan memanfaatkan berbagai media dan sumber belajar. (f) Kemampuan dalam melaksanakan evaluasi pembelajaran. (g) Kemampuan dalam menyusun program pembelajaran. (h) Kemampuan dalam melaksanakan unsur penunjang, misalnya administrasi sekolah, bimbingan dan penyuluhan. (i) Kemampuan dalam melaksanakan penelitian dan berpikir ilmiah untuk meningkatkan kinerja

Mulyasa dalam Jejen Musfah (2012: 27) mengartikan bahwa kompetensi guru merupakan perpaduan antara kemampuan personal, keilmuan, teknologi, sosial, dan spiritual yang secara kafah membentuk kompetensi standar profesi guru, yang mencakup penguasaan materi, pemahaman terhadap peserta didik, pembelajaran yang mendidik, pengembangan pribadi dan profesionalitas.Sejalan dengan yang telah diungkapkan oleh Mulyasa, Suhertian dikutip dalam Triyanto (2010: 62) mendefinisikan kompetensi guru menjadi tiga, yaitu (1) Kompetensi guru adalah kemampuan guru dalam mewujudkan tujuan-tujuan pendidikan yang telah direncanakan, (2) Kompetensi guru adalah ciri hakiki dari kepribadian guru yang menuntunnya ke arah pencapaian tujuan pendidikan yang telah ditentukan, (3) Kompetensi guru adalah perilaku yang dipersyaratkan untuk mencapai tujuan pendidikan.

Menurut Mulyasa (2009: 138) Kompetensi Profesional merupakan kompetensi yang harus dikuasai guru dalam kaitannya dengan pelaksanaan tugas utamanya mengajar. Peraturan Menteri Pendidikan Anak dan Kebudayaan Republik Indonesia Nomor 137 tahun 2014 tentang Standar Nasional Pendidikan Anak Usia Dini menjelaskan kompetensi guru PAUD mencakup kompetensi pedagogik, kepribadian, sosial, dan profesional (Kemdikbud: 2014). 


\begin{tabular}{|c|c|}
\hline Kompetensi & Sub Kompetensi \\
\hline III Profesional & \\
\hline $\begin{array}{l}\text { 1) Mengembangkan } \\
\text { materi, stuktur, dan } \\
\text { konsep bidang } \\
\text { keilmuxan yang } \\
\text { mendukung serta } \\
\text { sejalan dengan } \\
\text { kebutuhan dan } \\
\text { tahapan } \\
\text { perkembangan anak } \\
\text { usia dini. }\end{array}$ & $\begin{array}{l}\text { a) Menalaah konsep dasar } \\
\text { keilmuwan bidang } \\
\text { matematika, sains, Bahasa, } \\
\text { studisosial, seni, agama yang } \\
\text { sesuai dengan kebutuhan, } \\
\text { tahapan perkembangan dan } \\
\text { psikomotorik analk usia dini. } \\
\text { b) Mengorganisasikan konsep } \\
\text { dasar keilmuwan sebagai alat, } \\
\text { aktivitas, dan konten dalam } \\
\text { pengembangan anak usia } \\
\text { dini. }\end{array}$ \\
\hline $\begin{array}{l}\text { 2) Merancang berbagai } \\
\text { kegiatan } \\
\text { pengembangan } \\
\text { secara kreatif sesuai } \\
\text { dengan tahapan } \\
\text { perkembangan anak } \\
\text { usia dini. }\end{array}$ & $\begin{array}{l}\text { a) Merumuskan tujuan setiap } \\
\text { kegiatan pengembangan. } \\
\text { b) Menganalisis perkembangan } \\
\text { anak usia dini dalam setiap } \\
\text { bidang pengembangan. } \\
\text { c) Memilih materi berbagai } \\
\text { kegiatan pengembangan } \\
\text { sesuai dengan tingkat } \\
\text { perkembangan analk usia dini. } \\
\text { d) Mengorganisasikan kegiatan } \\
\text { pengembangan secara kreatif } \\
\text { sesuai dengan tingkat } \\
\text { perkembangan analk usia dini. }\end{array}$ \\
\hline $\begin{array}{l}\text { 3) Mengembangkan } \\
\text { keprofesional secara } \\
\text { berkelanjutan } \\
\text { dengan melakukan } \\
\text { tindakan reflektif. }\end{array}$ & $\begin{array}{l}\text { a) Melakukan reflektif terhadap } \\
\text { kineria sendiri secara terus } \\
\text { menerus. } \\
\text { b) Memanfatkan hasil refleksi } \\
\text { dalam rangka peningkatan } \\
\text { keprofesionalan. }\end{array}$ \\
\hline
\end{tabular}

Kompetensi Profesional dalam Standar Nasional Pendidikan, yang dijelaskan dalam pasal 28 ayat (3) butir c adalah kemampuan penguasaan materi pembelajaran secara luas dan mendalam yang memungkinkannya membimbing peserta didik memenuhi standar kompetensi yang di tetapkan dalam Standar Nasional Pendidikan.Dalam hal ini pengalaman mengajar, pelatihan, dan jenjang pendidikan yang telah diampunya menjadi dasar guru tersebut memiliki kompetensi dasar sebagai seorang guru dalam menjalani profesinya. Oleh karena itu kompetensi guru menjadi tuntutan dasar bagi seorang guru.

Hal tersebut diperkuat dengan pendapat Hamalik (2011: 24) guru professional harus mempunyai persyaratan, yang meliputi: (a) Memiliki bakat sebagai guru, (b) Memiliki keahlian sebagai guru, (c) Memiliki keahlian yang baik dan terintegrasi, (d) Memiliki mental yang sehat, (e) Berbadan sehat, (f) Memiliki pengalaman dan pengetahuan yang luas, (g) Guru adalah manusia berjiwa pancasila, (h) Guru adalah seorang warga negara yang baik.

Guru sebenarnya sudah mengembangkan dan melaksanakan kompetensi professional guru melalui program-program yang diadakan oleh satuan pendidikan dan yang dilakukan sendiri. Untuk mengetahui apakah guru telah memiliki kompetensi professional, maka seorang guru harus memenuhi indikator-indikator yang ada.Salah satu kompetensi yang penting untuk dimiliki adalah kompetensi profesional.

Menurut Badan Standar Nasional Pendidikan (2006: 88) kompetensi profesional adalah kemampuan penguasaan materi secara luas dan mendalam yang meliputi: (a) konsep, struktur dan metode keilmuan/tekhnologi/seni yang menaungi/koherensi dengan materi ajar; (b) materi ajar yang ada dalam kurikulum sekolah; (c) hubungan konsep antar mata pelajaran terkait; (d) penerapan konsep keilmuan dalam kehidupan sehari-hari; dan (e) kompetisi secara professional dalam konteks global dengan tetap melestarikan nilai dan budaya nasional.

Guru profesional dapat melaksanakan tugasnya sebagai pendidik pendidik, pengajar, pembimbing, pelatih dan penilai jika seorang guru memilik empat kompetensi dasar sebagai guru. Kompetensi pedagogik, kompetensi sosial, kompetensi kepribadian dan salah satunya adalah kompetensi profesional.Diperkuat dengan yang dijelaskan oleh Mulyasa (2009: 138) Kompetensi Profesional merupakan kompetensi yang harus dikuasai guru dalam kaitannya dengan pelaksanaan tugas utamanya mengajar.

Menurut M Shulton Masyhud (dalam Novan Ardy, 2015: 63) mengungkapkan bahwa untuk menjadi seorang guru yang profesional, hendaknya: (1) Terdidik secara baik (well educated), (2) Terlatih secara baik (well trained), (3) Dihargai dengan baik (well paid), (4) Terlindung secara baik (well protected), (5) Dikelola secara baik (well managed). Kompetensi profesional sebenarnya merupakan "payung", karena telah mencakup semua kompetensi lainnya. Sedangkan penguasaan materi ajar secara luas dan mendalam lebih tepat disebut dengan penguasaan sumber bahan ajar (disciplinary content) atau sering di sebut bidang studi keahlian. Hal ini mengacu pandangan yang menyebutkan bahwa sebagai guru yang berkompeten memiliki (1) pemahaman terhadap karakteristik peserta didik, (2) penguasaan bidang studi, baik dari sisi keilmuan maupun kependidikan, (3) kemampuan penyelenggaraan pembelajaran 
yang mendidik, dan (4) kemauan dan kemampuan mengembangkan profesionaitas dan kepribadian secara berkelanjutan.

Hasan Alwi dalam kamus besar bahasa Indonesia mengungkapkan bahwa anak adalah manusia yang masih kecil, yaitu yang baru berumur enam tahun.Anak usia dini adalah sosok individu yang sedang menjalani suatu proses perkembangan dengan pesat dan fundamental bagi kehidupan selanjutnya, anak usia dini berada pada rentang usia 0-8 tahun (NAEYC/Nasional Association for the Educationof Young Children).

Sujiono (dalam Nurani 2013: 6) Pada masa ini proses dan pertumbuhan dan perkembangan dalam berbagai aspek sedang mengalami masa yang cepat dalam rentang perkembangan hidup manusia. . Setiap proses perkembangan dan pertumbuhan yang di ajarkan harus melihat karakteristik dari segala aspek di setiap tahap perkembangan pada anak.

Hal tersebut sesuai dengan yang dijelaskan oleh John Amos Comenius dalam Yus (2011: 2) bahwa pendidikan harus di mulai sejak dini, sejak anak lahir pendidikan sudah perlu di mulai secara alami dengan memerhatikan aspek kematangan (maturation) dan memberi kesempatan pada anak untuk menggunakan seluruh inderanya.

Berbeda dengan pengertian secara intitusional maupun yuridis sebagaimana dikemukakan di atas, Bredekamp dan Copple dalam Suyadi (2013: 18) mengemukakan bahwa pendidikan anak usia dini mencakup berbagai program yang melayani anak dari usia lahir sampai dengan usia delapan tahun yang di rancang untuk meningkatkan perkembangan intelektual, sosial, emosi, bahasa, dan fisik anak.

Pendidikan Anak Usia Dini bertujuan untuk memfasilitasi pertumbuhan dan perkembangan anak secara optimal dan menyeluruh sesuai dengan norma dan nilai-nilai kehidupan yang dianut dan melalu Pendidikan Anak Usia Dini anak diharapkan dapat mengembangkan segenap potensi yang dimilikinya seperti intelektual, sosial, emosi, dan fisik motorik.

Suparlan dalam bukunya yang berjudul "Menjadi Guru Efektif", mengungkapkan hal yang berbeda tentang pengertian guru. Menurut Suparlan (2008: 12), guru dapat diartikan sebagai orang yang tugasnya terkait dengan upaya mencerdaskan kehidupan bangsa dalam semua aspeknya, baik spiritual dan emosional, intelektual, fisikal maupun aspek lainnya.

Menurut Ardy (2019: 103) Tugas profesi seorang guru meliputi kegiatan mendidik, mengajar, membimbing, mengarahkan melatih, dan menilai yang dilakukan oleh seseorang. Seorang guru juga berarti harus memiliki bekal pengetahuan, keterampilan, dan keahlian agar dapat menilai peserta didiknya.

Oleh karena itu, perlu diperhatikan secara sungguh-sungguh bagaimana memberikan prioritas yang tinggi pada guru. Sehingga mereka dapat memperoleh kesempatan untuk selalu meningkatkan kemampuannya melaksanakan tugasnya melakukan proses belajar mengajar yang baik. Kepada guru perlu diberikan dorongan dan suasana yang kondusif untuk menemukan berbagai alternative metode dan cara mengembangkan proses pembelajaran sesuai perkembangan jaman.

Berdasarkan latar belakang masalah mengenai pentingnya kompetensi dasar yabg harus dimiliki oleh seorang tenaga pendidik sebagai tenaga profesional melalui penelitian yang berjudul "Gambaran Kompetensi Profesional Guru PAUD Mangga Paninggilan Ciledug".

Penelitian ini bertujuan untuk mendeskripsikan kemampuan kompetensi profesional yang dimiliki oleh guru PAUD Mangga Paninggilan, serta upaya upaya guru dalam melaksanakan tugasnya secara maksimal.

\section{METODE PENELITIAN}

Penelitian ini menggunakan penelitian kualitatif seperti yang dijelaskan oleh Bogdan dan Taylor (dalam Moleong, 2011: 4) mendefinisikan metodologi kualitatif sebagai prosedur penelitian yang menghasilkan data deskriptif berupa kata-kata tertulis atau lisan dari orangorang dan perilaku yang dapat diamati.Dalam penelitian ini, pendekatan yang digunakan adalah pendekatan kualitatif deskriptif yaitu pendekatan yang dimaksudkan untuk menjelaskan fenomena atau karakteristik individu, situasi atau kelompok tertentu secara 
akurat. Pendekatan kualitatif deskriptif adalah data yang dikumpulkan berupa kata-kata, gambar, dan bukan angka (Moleong, 2011: 11). Dengan demikian laporan penelitian akan berisi kutipan-kutipan data untuk memberi gambaran penyajian laporan tersebut.

Penelitian ini dilakukan di PAUD Mangga Paninggilan Ciledug, Kota Tangerang. Sumber penelitian pada penelitian ini berjumlah 4 orang, terdiri pengelola PAUD, guru/tendik PAUD Mangga, dan pengurus organisasi Himpaudi.

Teknik pengumpulan data yang digunakan dalam penelitian kualitatifmerupakan langkah paling strategis dalam penelitian karena tujuan utama dari penelitian adalah mendapatkan data, Sugiyono (2016: 224). teknik pengumpulan data dilakukan secara naturan dengan metode wawancara baik kepada pengelola Paud, guru, serta pengurus Himpaudi untuk memperoleh data mengenai kemampuan Kompetensi Profesional guru. Observasi dilakukan untuk memperoleh data mengenai kompetensi profesional yang dimiliki guru Paud Mangga Paninggilan. Sementara dokumentasi digunakan untuk memperkuat data-data yang sudah ada seperti hasil data dari wawancara dan observasi. Data dari hasil dokumentasi yang didapat oleh peneliti dapat berupa arsip-arsip yang meliputi data pelengkap dan penunjang.

\section{HASIL DAN PEMBAHASAN}

Kompetensi profesional guru PAUD Mangga memang sudah baik namun memang belum maksimal dalam penyajian materi pembelajaran yang menarik, kreatif serta dapat lebih mengembangkan keprofesionalan sebagai tenaga professional dalam hal peningkatan mutu pendidikan bagi anak didik di PAUD Mangga Paninggilan.

Guru di PAUD Mangga Paninggilan dalam penyusunan kegiatan pembelajaran berupaya untuk memberikan materi yang sesuai dengan tingkat pencapaian perkembangan peserta didik. Sebagai salah satu upaya untuk menjadi tenaga pendidik yang professional guru di PAUD Mangga Paninggilan, selalu berupaya meningkatkan kemampuannya melalui berbagai cara. Mulai dari mengikuti pelatihan, workshop dan menggali informasi dari sesama guru maupun internet.

Mengembangkan materi, struktur, dan konsep bidang keilmuwan yang mendukung serta sejalan dengan kebutuhan dan tahapan perkembangan anak usia dini.

Kompetensi yang harus dimiliki oleh seorang tenaga pendidik yaitu kemampuan mengembangkan materi, struktur, dan konsep bidang keilmuwan yang mendukung serta sejalan dengan kebutuhan dan tahapan perkembangan anak usia dini.Guru di PAUD Mangga Paninggilan kompetensi yang dimiliki dapat dikatakan masih belum maksimal karena dalam penyusunan perangkat pembelajaran guru di PAUD Mangga ini masih menggunakan RPP yang sudah ada. Banyak lembaga PAUD yang copypaste rencana pembelajaran dari tempat lain. Hal ini membuktikan bahwa masih banyak guru PAUD yang belum mampu membuat perencanaan pembelajaran yang baik, serta tidak memahami kompetensi apa saja yang harus dikembangkan bagi perkembangan anak.

Di dalam menganalisis materi serta kegiatan pengembangan yang sesuai dengan tahapan perkembangan anak usia dini, guru di PAUD Mangga Paninggilan hanya menggunakan kemampuannya secara individu dengan melihat dan menilai apa yang ada dan belum mengetahui secara mendetail tentang tahapan perkembangan anak usia dini. Jadi dalam penyusunan laporan penilaian perkembangan anak didik guru di PAUD Mangga Paninggilan masih menggunakan penilaian sederhana, belum mampu merinci setiap tahapan perkembangan anak didik.

\section{Merancang berbagai kegiatan pengembangan secara kreatif sesuai dengan tahapan perkembangan anak usiadini}

Guru PAUD Mangga Paninggilan dalam mengembangkan materi pembelajaran berupaya memberikan materi secara kreatif guru memilih materi bidang pengembangan sesuai dengan tingkat perkembangan peserta didik. Hal ini terlihat dari cara guru menyampaikan atau memberikan materi selalu berpedoman dengan Rencana Pelaksanaan Pembelajaran Harian (RPPH) yang telah di buat, sehingga materi 
yang diberikan sudah terstruktur sesuai dengan materi yang harus di berikan pada hari itu.

Selain itu, materi yang diberikan juga sesuai dengan perkembangan dan usia peserta didik. Contohnya pada materi bertema profesi dengan kegiatan menggunting tingkat kesulitannya di sesuaikan dengan kemampuan peserta didik.

\section{Mengembangkan keprofesional secara berkelanjutan dengan melakukan tindakan reflektif}

Guru di PAUD Mangga Paninggilan dalam mengembangkan keprofesionalannya secara berkelanjutan melalui tindakan reflektif dengan cara melakukan refleksi terhadap kinerja sendiri secara terus menerus.Hal ini terlihat dari cara guru setiap selesai pembelajaran guru di PAUD Mangga Paninggilan melakukan evaluasi sendiri kegiatan pembelajaran pada hari itu. Apa yang kurang dalam kegiatan pada hari itu. Contohnya pada saat pembelajaran anak ada yang tidak mau menulis, maka hal tersebut masuk dalam catatan anekdot guru.

Di dalam mengembangkan keprofesionalannya secara berkelanjutan melalui tindakan reflektif dengan caramemanfaatkan hasil refleksi untuk meningkatkan keprofesionalannya. Hal ini terlihat dari cara guru yang selalu mendiskusikan masalah apa yang dihadapi di kelas kepada kepala sekolah untuk mencari solusinya. Selain itu juga untuk dijadikan sebagai ajang intropeksi diri. Contohnya ketika anak dikelas tidak mau mengikuti pembelajaran dengan baik maka itu menjadi bahan diskusi dan mencari solusinya.

\section{SIMPULAN DAN SARAN}

Guru di PAUD Mangga Paninggilan menyampaikan materi kepada peserta didik dengan menggunakan bahasa yang mudah dimengerti oleh anak, menggunakan berbagai metode dan media yang sangat menarik serta dekat dengan lingkungan anak. Guru mengkombinasikan semua ilmu dasar, menggunakan alat permainan anak, dan guru sangat menguasai permainan tersebut. Guru menyusun Rencana Pelaksanaan Program Harian (RPPH) sesuai dengan kemampuan anak. Sering kali guru menggunakan metode bercerita menggunakan tokoh kartun yang digemari anak dalam menyampaikan materi agar anak tidak jenuh. Selain itu dalam menyampaikan materi guru juga menggunakan bahasa yang mudah dimengerti anak.

Mengembangkan keprofesionalan secara berkelanjutan dengan melakukan tindakan reflektif, guru PAUD Mangga Paninggilan sering kali berdiskusi dengan kepala sekolah dan rekan kerja yang lain untuk mendiskusikan dan mencari solusi dari masalah apa yang dihadapi oleh guru ketika dikelas. Guru PAUD Mangga Paninggila dalam upaya mengembangkan keprofesionalannya juga banyak belajar dari berbagai sumber seperti internet, mengikuti seminar, mengikuti workshop dan lain sebagainya. Dalam kemampuannya menggunakan teknologi informasi guru di PAUD Mangga Paninggilan mencari media untuk mengajar di internet.

Adapun saran bagi lembaga PAUD Mangga Paninggilan diharapkan bagi guru sebagai tenaga pendidik terus memiliki semangat dalam meningkatkan pengetahuan dan keterampilannya agar terus dapat meningkatkan kemampuan professional yang dimiliki. Khususnya pada indikator kompetensi profesional mengenai pengembangan keprofesionalan secara berkelanjutan dengan melakukan tindakan reflektif seperti melaksanakan penelitian tindakan kelas karena saat ini belum ada guru PAUD yang melakukan penelitian tindakan kelas yang berkaitan dengan kompetensi profesional.Untuk lembaga PAUD Mangga Paninggilan diharapkan dapat terus membantu guru di PAUD Mangga Paninggilan untuk mengembangkan kemampuannya.

\section{DAFTAR PUSTAKA}

Ardy, N. (2015). Etika profesi keguruan. Yogyakarta: Gava Media.

Arikunto, S. (2012). Dasar-dasar evaluasi pendidikan. Jakarta: Bumi Aksara.

Arikunto, S. (2010). Evaluasi program pendidikan. Jakarta: Bumi Aksara.

Departemen Pendidikan Nasional. (2014). Peraturan Menteri Pendidikan Nasional Nomor 137 Tahun 2014. tentang standar nasional pendidikan anak usia dini, Jakarta: Depdiknas

Departemen Pendidikan Nasional. (2005). Peraturan Pemerintah Republik Indonesia 
Nomor 19 tahun 2005 tentang standar nasional pendidikan, Jakarta: Departemen Pendidikan Nasional.

Departemen Pendidikan Nasional. (2005). Undang-Undang Nomor 14 Tahun 2005, tentang guru dan dosen. Jakarta: Depdiknas.

Departemen Pendidikan Nasional. (2007). Peraturan Menteri Pendidikan Nasional Nomor 16 Tahun 2007, tentang standar kualifikasi akademik dan kompetensi guru. Jakarta: Depdiknas.

Fadillah, M. (2012). Desain pembelajaran PAUD: tinjauan teoritik dan praktik. Yogyakarta: Ar-Ruzz Media.

Hamalik, O. (2011). Proses belajar mengajar. Jakarta: Bumi Perkasa.

Hariwijaya. (2007). Metodologi dan penulisan skripsi, tesis dan disertasi. Yogyakarta: Parama Ilmu.

Husaini, U. (2013). Praktik dan riset pendidikan. Jakarta: Bumi Aksara.

Kamil, M. (2012). Model pendidikan dan pelatihan. Bandung: Alfabeta.

Kamil, M. (2012). Konsep aplikasi. Bandung: Alfabeta.

Lexy J. M. (2017). Metode penelitian kualitatif. Bandung: Rosdakarya.

Mudlofir, A. (2012). Pendidikan profesional. Jakarta: Rajawali Pers.

Musfah, J. (2012). Peningkatan kompetensi guru. Jakarta: Prenada Media Group.
Mulyasa. (2009). Standar kompetensi dan sertifikasi guru. Bandung: PT Remaja Rosdakarya.

Nasrul. (2012). Profesi dan etika keguruan. Yogyakarta: Aswaja Pressindo.

Nurfuadi. (2012). Profesionalisme guru. Purwokerto: STAIN Press.

Sujiono, Y.N. (2013). Konsep dasar pendidikan anak usia dini. (Jakarta: PT Indeks)

Safrudin, C.A.J., Arikunto, S. (2010). Evaluasi program pendidikan. Jakarta: Bumi Aksara.

Sugiyono. (2016). Metode penelitian kuantitatif, kualitatif, dan $R \& D$. Bandung: Alfabeta

Sukmadinata, N.S. (2009). Metode penelitian pendidikan. Bandung: PT Remaja Rosdakarya.

Suparlan. (2008). Menjadi guru yang efektif. Yogyakarta: Hidayat.

Triyanto. (2010). Model pembelajaran terpadu. Jakarta: Bumi Aksara.

Ulfah, Suyadi. (2013). Konsep dasar PAUD. Bandung: Remaja Rosdakarya.

Uno, Hamzah. (2010). Profesi kependidikan: problema dan reformasi pendidikan. Jakarta: Bumi Aksara.

Usman, Uzer. (2011). Menjadi Guru Profesional. Bandung: Remaja Rosdakarya.

Yus, Anita. (2011). Model pendidikan anak usia dini. Jakarta: Kencana 